\title{
Implementasi Scaffolding dalam Pembelajaran BIPA di Kelas Pemula
}

\author{
Gamal Kusuma Zamahsari ${ }^{1}$, A. H. Roffi' uddin $^{2}$, Widodo HS $^{2}$ \\ ${ }^{1}$ Institut Teknologi Kreatif Bina Nusantara Malang \\ ${ }^{2}$ Pendidikan Bahasa Indonesia-Universitas Negeri Malang
}

\begin{tabular}{l}
\hline \hline INFO ARTIKEL \\
\hline Riwayat Artikel: \\
Diterima: 11-10-2018 \\
Disetujui: $21-01-2019$ \\
\hline
\end{tabular}

Kata kunci

scaffolding;

teachers;

BIPA learning;

pengajar;

pembelajaran BIPA

\begin{abstract}
ABSTRAK
Abstract: This article aims to describe the forms and functions of scaffolding in BIPA learning interactions at the beginner class. The method used is qualitative. The results of this study indicate that teachers in the learning interaction use some variation forms and functions of scaffolding. The visible forms are modeling, bridging, schema building, metacognition development, contextualisation, ilustration, exhibition, and correction. The visible functions are demonstration, recruitment, giving information, direction, explanatory, and direction maintenance. BIPA instructors use these forms and functions to help understand learning material to learners.
\end{abstract}

\begin{abstract}
Abstrak: Artikel ini bertujuan mendeskripsikan bentuk dan fungsi scaffolding dalam pembelajaran BIPA di kelas pemula. Metode yang digunakan adalah kualitatif dengan teknik rekam catat. Hasil penelitian ini menunjukkan bahwa pengajar BIPA menggunakan beberapa bentuk dan fungsi scaffolding yang bervariasi. Bentuk yang muncul, yaitu pemodelan, penghubung, pembangunan skemata, pengembangan metakognisi, kontekstualisasi, ilustrasi, peragaan, dan koreksi, sedangkan fungsi yang muncul yaitu mendemonstrasikan, memfokuskan, memberikan informasi, membimbing, menjelaskan, dan mengarahkan. Pengajar BIPA menggunakan bentuk dan fungsi tersebut untuk membantu memahamkan materi pembelajaran kepada pemelajar.
\end{abstract}

\section{Alamat Korespondensi:}

Gamal Kusuma Zamahsari

Institut Teknologi Kreatif Bina Nusantara Malang

Green Boulevard No. 1 Araya, Purwodadi, Blimbing, Kota Malang, Jawa Timur 65126

E-mail: zgams21@gmail.com

Pengajar bahasa Indonesia bagi penutur asing (BIPA) bertugas memberikan pemahaman materi bahasa dan budaya Indonesia kepada pemelajar BIPA. Keberhasilan dalam memahamkan materi tersebut memerlukan upaya khusus karena pembelajaran BIPA memiliki perbedaan dengan pembelajaran bahasa Indonesia bagi pemelajar Indonesia. Banyak aspek yang membuatnya berbeda, di antaranya pemelajar BIPA merupakan orang asing yang memiliki bahasa serta latar budaya yang berbeda. Penjelasan kosakata, afiksasi, struktur kalimat, dan wacana dalam bahasa Indonesia harus dikemas dengan baik ketika menjelaskan kepada para pemelajar BIPA sehingga pembelajaran menjadi lebih bermakna.

Pengajar BIPA harus melakukan inovasi penjelasan yang dapat membantu pemelajar BIPA memahami materi pembelajaran. Teknik menjelaskan dan membantu pemelajar memahami suatu konsep yang sulit dipahami harus dimiliki oleh pengajar BIPA. Tidak selamanya penjelasan materi pembelajaran dengan cara menerjemahkan ke dalam bahasa asli pemelajar atau bahasa asing adalah cara yang efektif. Penerjemahan secara langsung dapat dilakukan, tetapi dalam kondisi tertentu tidak karena bahasa dipengaruhi oleh budaya dan kondisi yang melatarbelakanginya. Contohnya istilah masuk angin yang mungkin tidak ada dalam konsep bahasa pemelajar BIPA. Istilah tersebut tidak dapat dijelaskan dengan cara penerjemahan secara langsung.

Selain hal tersebut pembelajaran BIPA untuk pebelajar dewasa harus dipersiapkan dengan baik dan sesuai. Kondisi belajar bahasa pertama dan kedua itu memiliki perbedaan yang kompleks karena perbedaan usia, perbedaan pribadi dan perbedaan lingkungan dapat memengaruhinya (Akhter, Amin, Saeed, Muhammad, \& Abdullah, 2016). Selain itu, perbedaan fonemik dan struktur bahasa antara bahasa pertama dan bahasa kedua memiliki dampak penting bagi pemelajar bahasa kedua dalam memproduksi bahasa target. Contoh paling sederhana penjelasan nama-nama hari yang seharusnya tidak dijelaskan seperti mengajarkan bahasa untuk anak-anak TK. Misalnya, pemelajar diajak bernyanyi lagu untuk anak-anak. Pemelajar dewasa sudah memiliki perasaan psikologis yang perlu diperhatikan. Ada pemelajar yang mungkin mau mengikuti instruksi tersebut dan ada pula yang mungkin merasa hal tersebut memalukan. Keterampilan belajar bahasa kedua dipengaruhi perasaan psikologis dan emosional sebagai bahasa ego, kecemasan, ragu-ragu dan malu. Ego merupakan salah satu faktor paling penting yang menghambat kemampuan belajar bahasa kedua pada orang dewasa (Abdullah, 2015).

Selama ini problematika tentang cara menjelaskan materi pembelajaran kepada pemelajar BIPA masih menjadi perbincangan sehingga muncul istilah bahasa tarzan sebagai jawabannya. Hal tersebut memberikan pengertian bahwa pembelajaran BIPA merupakan pembelajaran yang memiliki warna tersendiri dibandingkan pembelajaran bahasa Indonesia bagi 
orang Indonesia. Penelitian ini dilakukan untuk membahas persoalan pembelajaran BIPA menggunakan teori scaffolding. Penelitian tentang scaffolding dalam interaksi pembelajaran BIPA ini penting dilakukan untuk membedah persoalan tersebut. Selain fenomena tersebut, penelitian mengenai scaffolding dalam interaksi pembelajaran BIPA di kelas pemula ini juga berdasar pada aturan dalam program BIPA yang melarang penggunaan bahasa Inggris. Aturan tersebut menuntut para pengajar mencari cara untuk menjelaskan konsep bahasa Indonesia yang sesuai.

Sekarang para peneliti mulai mempertimbangkan teori model interaksional, misalnya teori belajar scaffolding dan zona pengembangan proksimal (Vygotsky) dalam penelitian kelas (Azabdaftari, 2013). Scaffolding dikembangkan sebagai sebuah bentuk pembelajaran untuk menjelaskan tentang suatu bantuan yang ditawarkan oleh pengajar atau teman sejawat untuk mendukung tercapainya tujuan pembelajaran. Dalam proses scaffolding, pengajar membantu memberikan pemahaman dalam menyelesaikan tugas atau konsep-konsep yang sulit bagi para pemelajar. Pengajar hanya membantu pemelajar dengan memberikan arahan atau media dalam mengerjakan tugas-tugas yang sulit dikuasai pemelajar, namun tanggung jawab penyelesaian tugas tetap pada diri pemelajar. Ada kemungkinan dalam mengerjakan tugas, pemelajar melakukan beberapa kesalahan, namun dengan mediasi atau bantuan baik berupa membimbing atau petunjuk yang diberikan pengajar, pemelajar dapat mengerjakan tugas-tugas tersebut dan mencapai tujuan.

Scaffolding merupakan bantuan kebahasaan yang digunakan untuk membangun percakapan bersama antara penutur asli dan pemelajar bahasa asing, dalam sebuah intraksi dengan cara menuntun dan membantu pemelajar untuk menyelesaikan wacana (Freeman \& Long, 1991). Pendapat lain mengatakan, scaffolding bukan sekadar sebuah bantuan semata kepada pemelajar, melainkan sebuah dukungan kepada pemelajar dalam rangka memperoleh pengetahuan baru yang lebih kompleks untuk dapat menyelesaikan tugas-tugas pada konteks yang baru (Hammond \& Gibbons, 2008). Pengajar mendukung pemelajar untuk mengetahui bagaimana bukan sekadar apa dalam memahami materi pelajaran.

\section{METODE}

Penelitian ini bertujuan untuk mendeskripsikan bentuk dan fungsi scaffolding dalam pembelajaran BIPA di kelas pemula. Data penelitian ini berupa transkrip tuturan pengajar BIPA yang mengandung scaffolding dalam interaksi pembelajaran di kelas pemula. Sumber data penelitian ini adalah interaksi pengajar dan pemelajar BIPA kelas pemula. Subjek penelitian berjumlah tiga pengajar BIPA yang berpengalama dan data diambil di dua kelas pemula. Data dikumpulkan selama proses pembelajaran berlangsung ketika terjadi interaksi antara pengajar dan pemelajar. Teknik pengumpulan data yang digunakan adalah observasi, perekaman, dan catatan lapangan. Kegiatan observasi dalam penelitian ini dilakukan dengan cara peneliti berperan sebagai pengajar sit-in. Observasi dilakukan untuk mengetahui topik yang akan diteliti dapat dilakukan, menentukan subjek penelitian, dan mengamati hal-hal yang tidak dapat direkam sebagai catatan lapangan.

Teknik perekaman digunakan untuk mendapatkan data audio. Teknik ini digunakan dengan bantuan alat perekam berupa telepon genggam yang dilengkapi fitur perekam audio. Perekaman dikondisikan sedemikian rupa agar tuturan yang direkam dapat menghasilkan data yang alamiah sesuai tujuan penelitian ini dan tidak mengganggu pemelajar. Oleh karena itu, telepon genggam dipilih sebagai alat perekam yang bersifat hemat, praktis, dan efisien. Perekaman dilakukan secara terus menerus dan berulangulang, sampai diperoleh data yang dibutuhkan. Perekaman dalam penelitian ini dilakukan selama tujuh kali pertemuan pembelajaran BIPA di kelas pemula. Setelah melakukan perekaman, peneliti mentranskripsikan hasil rekaman secara bertahap. Analisis rekaman yang sudah ditranskrip dilakukan dengan dua tahap. Pertama, peneliti mengidentifikasi semua bagian dari interaksi pembelajaran yang mengandung teknik scaffolding. Kedua, setelah tahap pertama selesai, data teknik scaffolding dikelompokkan sesuai bentuk dan fungsi scaffolding kemudian dibahas secara komprehensif.

\section{HASIL}

Penelitian ini berfokus pada dua hal tentang scaffolding, yaitu bentuk dan fungsi scaffolding yang diimplementasikan pengajar BIPA dalam pembelajaran di kelas pemula. Berikut ini hasil temuan penelitian mengenai bentuk dan fungsi scaffolding dalam interaksi pembelajaran di kelas pemula.

\section{Bentuk Scaffolding dalam Pembelajaran BIPA}

Hasil penelitian tentang bentuk scaffolding yang muncul dalam pembelajaran BIPA di kelas pemula, meliputi (1) pemodelan, (2) penghubung, (3) pembangunan skemata, (4) pengembangan metakognisi, (5) kontekstualisasi, (6) ilustrasi, (7) peragaan, dan (8) koreksi.

\section{Fungsi Scaffolding dalam Pembelajaran BIPA}

Hasil penelitian tentang fungsi scaffolding yang muncul dalam pembelajaran BIPA di kelas pemula meliputi (1) mendemonstrasikan, (2) memfokuskan, (3) memberikan informasi, (4) membimbing, (5) menjelaskan, dan (6) mengarahkan. Dari kedelapan bentuk scaffolding berhubungan dengan enam fungsi scaffolding ini. Fungsi memfokuskan berhubungan dengan bentuk penghubung. Fungsi mengarahkan berhubungan dengan bentuk koreksi. 
Fungsi mendemonstrasikan berhubungan dengan bentuk pemodelan. Fungsi menjelaskan berhubungan dengan bentuk kontekstualisasi, ilustrasi, dan peragaan. Fungsi memberikan informasi berhubungan dengan bentuk pembangunan skemata. Fungsi membimbing berhubungan dengan bentuk pengembangan metakognisi

\section{PEMBAHASAN \\ Pemodelan dan Fungsinya}

Penyampaian materi yang mudah dipahami pemelajar BIPA perlu diterapkan oleh pengajar. Pemodelan merupakan salah satu cara untuk menyampaikan materi. Pengajar memberikan model penggunaan bahasa dari materi yang diajarkan sehingga pemelajar memperoleh masukan bahasa melalui materi tersebut.Pengajar BIPA menerapkan pemodelan untuk menyampaikan materi yang memerlukan contoh langsung. Pemodelan yang dimaksud berupa sebuah tindakan pemberian contoh dari pengajar yang dapat ditirukan oleh para pemelajar. Pemelajar memerlukan contoh yang jelas dan dapat ditiru oleh mereka (Walqui, 2006). Berikut ini salah satu data yang menunjukkan bentuk pemodelan.

(1a) Konteks: Pengajar melakukan pemodelan tentang bagaimana bertanya identitas orang lain

P: Saling bertanya. Contoh Mbak Risky siapa nama tutor Mbak Risky?

P: Nama tutor saya Mbak Mega.

P: Mbak Mega berasal dari mana?

P: Mbak Mega berasal dari Kediri.

P: Bertanya Mbak Risky!

P: Siapa nama peer tutor Anda Mas Bas?

P: Nama peer tutor saya Mas Sulton, contoh, saling bertanya mengerti? Silakan!

Data (1a) tersebut menunjukkan pengajar melakukan pemodelan berkomunikasi tentang cara bertanya identitas orang lain. Pengajar secara langsung mempraktikkan sebuah dialog dengan pengajar lain untuk memberikan contoh kepada pemelajar. Pemelajar dapat menirukan model berbahasa Indonesia yang dicontohkan oleh pengajar sehingga contoh yang disajikan dapat menjadi masukan penggunaan bahasa Indonesia. Pemodelan sebagai salah satu bentuk scaffolding, banyak digunakan dalam pembelajaran (Pea, 2004). Pemodelan merupakan teknik yang lazim digunakan dalam pembelajaran. Dengan demikian, teknik pemodelan dipandang efektif bagi para pengajar.

Pengajar tidak hanya memberikan pemodelan berupa contoh penggunaan bahasa, tetapi juga memberikan contoh cara melakukan permainan kelas. Pemodelan ini disajikan untuk memberikan instruksi aktivitas permainan sehingga pemelajar dapat memahami perintah pengajar dan melakukannya sesuai target pembelajaran. Permainan merupakan bantuan bagi pemelajar dan wujud kreativitas para pengajar BIPA. Pengajar yang kreatif tidak hanya menyajikan materi sebatas dari buku teks. Mereka mencari cara orisinil untuk menciptakan pembelajaran yang menggunakan buku teks, media pembelajaran, dan mencerminkan gaya mengajarnya sendiri (Richards, 2013:26). Berikut data (1b) tentang pemodelan permainan pembelajaran materi kata negasi.

(1b) Konteks: Pengajar memberikan contoh permainan tebak benda untuk melatihkan materi kata negasi (tidak dan bukan).

P: Mbak Rizki punya sesuatu. Mas dan Mbak menebak, berpikir, contoh,

P: Mbak Rizki apa itu buku?

P: Bukan.

P: Apa itu bolpoin?

P: Bukan.

P: Apa itu uang?

P: Bukan uang.

P: Apa itu biru?

P: Bukan.

P: Apa itu makanan?

P: Bukan...

P: Ini bukan makanan.

P: Apa itu minum?

P: Apa itu minuman?

P: Ya.

P: Air? P: Ya Benar.

Sejak penelitian terkini tentang scaffolding melalui pemodelan, penelitian mengenai bahasa imitasi juga melibatkan ulasan tentang pemodelan karena pemodelan dapat dianggap sebagai bentuk scaffolding. Berdasarkan jenisnya pemodelan termasuk dalam jenis scaffolding ahli dan heuristik karena pengajar sebagai ahli memberikan sebuah model penggunaan bahasa untuk membantu membangun konsep para pemelajar dalam menggunakan bahasa target. Pada tataran domain pemodelan termasuk dalam jenis scaffolding heuristik dan pada tataran agency pemodelan termasuk dalam jenis scaffolding ahli (Holton \& Clarke, 2006). 
Bentuk pemodelan berhubungan dengan fungsi mendemonstrasikan dalam scaffolding. Fungsi mendemonstrasikan termasuk tindakan peragaan dan pemodelan dari sebuah bentuk ideal yang disajikan kepada pemelajar yang dapat memberikan sebuah solusi dalam pembelajaran (Wood, Bruner, \& Ross, 1976). Sebagaimana penjelasan sebelumnya bahwa pemodelan dilakukan untuk memberikan contoh ideal yang dapat ditiru oleh pemelajar. Pemodelan berhubungan dengan fungsi mendemonstrasikan dari sebuah contoh sebagai solusi yang ideal (Zhao \& Chen, 2014).

Berdasarkan pembahasan tersebut memberikan pengertian bahwa teknik pemodelan yang dilakukan pengajar BIPA di kelas pemula ini mendukung pendapat bahwa pemelajar memerlukan contoh yang jelas untuk dapat ditiru oleh mereka (Walqui, 2006). Ketika pengajar menyampaikan materi baru, pemelajar perlu melihat dan mengamati sebuah contoh terlebih dahulu karena interaksi antara pemelajar dan pengajar dalam hal tersebut merupakan langkah yang penting. Pengajar BIPA dalam penelitian ini tidak hanya mencontohkan kaidah bahasa saja, tetapi pengajar mencontohkan penggunaan bahasa dalam komunikasi sehari-hari yang disertai konteks dan makna yang melatarbelakanginya. Bahkan, pengajar juga menyisipkan unsur budaya yang tak tampak (intangible culture) dalam interaksi berbahasa di kehidupan sehari-hari. Berdasarkan temuan tersebut dapat dikatakan bahwa pemodelan yang muncul sesuai dengan faktor yang melatarbelakanginya yaitu jenis topik dan materi yang diajarkan. Dalam materi penggunaan bahasa komunikasi, pengajar melakukan pemodelan dengan membuat contoh dialog. Dalam materi kaidah bahasa, misalnya struktur kalimat pengajar melakukan pemodelan dengan meberikan contoh bentuk kalimat dengan struktur yang sesuai. Selain itu, pengajar mengemas materi dalam permainan. Pengajar melakukan pemodelan dengan mencontohkan cara bermain permainan tersebut.

Scaffolding bukan sekadar sebuah bantuan semata kepada pemelajar, melainkan sebuah dukungan kepada pemelajar dalam rangka memperoleh pengetahuan baru yang lebih kompleks untuk dapat menyelesaikan tugas-tugas pada konteks yang baru (Hammond \& Gibbons, 2008). Pemberian model yang kompleks sesuai dengan penggunaan bahasa dalam lingkungan komunikasi sebenarnya mendukung pemerolehan bahasa yang kompleks sehingga pemelajar dapat mengatasi dan menyelesaikan tugas-tugas berbahasa dalam konteks yang baru.

\section{Penghubung dan Fungsinya}

Pemahaman adalah pemahaman mendalam yang memerlukan jalinan pengetahuan baru ke dalam bentuk struktur mental (Tharp \& Gallimore, 1990). Sebelum memberikan pengetahuan yang baru pengajar tentu dapat membangun pengetahuan awal pemelajar dengan cara menggali informasi yang dimiliki pemelajar sebelum memberikan pengetahuan yang baru. Bentuk scaffolding penghubung digunakan sebagai upaya pengajar menjembatani informasi baru dengan cara menghubungkannya dengan pengalaman dan pengetahuan pemelajar yang telah diperoleh sebelumnya. Berikut ini salah satu data yang menunjukkan bentuk scaffolding penghubung.

(2)Konteks: Pengajar mengawali pembelajaran dengan bertanya mengenai peer tutor pemelajarmasing-masing.

P: Oke, kemarin bertemu tutor? (a)

M: (diam)

P: berbicara dengan tutor?

M: Ya

P: Berbicara dengan tutor ya? (b)

M: Saya tidak tahu eh, where eh di mana tutor.

P: Mbak siapa? (c)

M: Mbak Emilda

P: Oh, Mbak Emilda sakit? sakit? tidak? (d)

M: Oh, tidak tidak, eh, ehm. Sibuk.

P: Mas Daniel bertemu dengan peer tutor? (e)

M: Ya

P: Ya siapa? (f)

M: Imam

P: Baik, sekarang silakan Mbak dan Mas duduk. Mbak Kathryn dengan Mas Daniel, Mbak Julia dengan Mbak Sarah,

Mbak Samantha dengan Mbak Risky ya saling bertanya. Contoh Mbak Risky siapa nama tutor Mbak Risky?

P: Nama tutor saya Mbak Mega

P: Mbak Mega berasal dari mana?

P: Mbak Mega berasal dari Kediri.

P: Bertanya Mbak Risky!

P: Siapa nama peer tutor Mas Bas?

P: Nama peer tutor saya Mas Sulthon. Contoh saling bertanya. Silakan! $(g)$

(Pemelajarpraktik berdialog)

Data (2a-2f) tersebut menunjukkan bahwa pengajar berupaya menghubungkan informasi yang pernah dialami sebagai jembatan untuk mempermudah pemelajar dalam memahami materi yang akan dipelajari. Setelah pengajar bertanya mengenai pengalaman pemelajar dengan peer tutor masing-masing, pengajar mulai menghubungkannya dengan dialog tentang materi bertanya identitas orang lain, data $(2 \mathrm{~g})$. Dialog tersebut menunjukkan pengajar menghubungkan informasi tentang identitas tutor 
untuk memahamkan materi yang dipelajari. Upaya pengajar menghubungkan informasi yang dianggap dekat dengan pemelajar tersebut akan memfokuskan pemelajar terhadap contoh yang dihadirkan oleh pengajar. Oleh sebab itu, pemelajar diharapkan dapat memahami materi yang diajarkan dengan baik. Penghubung dan pemfokusan merupakan ciri scaffoding yang digunakan dalam pembelajaran (Pea, 2004). Pendapat selanjutnya mengatakan bahwa penghubung dan pemfokusan merupakan indikasi dari sumber yang relevan untuk penyederhanaan tugas dan pemfokusan perhatian pemelajar (Zhao \& Chen, 2014).

Teknik scaffolding penghubung berkaitan dengan fungsi memfokuskan. Fungsi memfokuskan hadir dalam interaksi pembelajaran ketika pengajar berusaha memfokuskan pemelajar terhadap materi dan tugas yang diberikan. Fungsi tersebut dapat memfokuskan pemelajar terhadap tugas, contohnya pengajar mengarahkan atensi pemelajar dan menjaga ketertarikan mereka terhadap tugas yang diberikan oleh pengajar dalam kegiatan pembelajaran (Hall, 2001). Scaffolding penghubung yang dilakukan oleh pengajar BIPA di kelas pemula dalam pembahasan ini mendukung pendapat Walqui (2006) bahwa scaffolding penghubung (bridging) membangun hubungan personal antara pemelajar dan materi pelajaran serta menunjukkan materi baru relevan dengan kehidupan mereka.

\section{Pembangunan Skemata dan Fungsinya}

Membangun pemahaman adalah suatu permasalahan ketika menautkan informasi baru pada pengetahuan awal pemelajar. Oleh karena itu, pengajar perlu membantu pemelajar melihat hubungan-hubungan antara skemata yang dimiliki dengan informasi baru yang akan dipahami (Walqui, 2006). Berdasar data yang ditemukan dalam interaksi pembelajaran BIPA di kelas pemula, pengajar mencoba meminta pemelajar untuk melihat hubungan antara informasi baru yang disampaikan dengan skemata yang dimiliki. Namun, pemelajar terlihat tidak memahami maksud ujaran pengajar. Pengajar mencoba memberikan contoh hingga akhirnya pemelajar dapat merespons dan menyadari maksud dari ujaran pengajar. Sebagaimana dalam data berikut.

(3) Konteks: Pengajar membacakan sebuah bacaan tentang identitas diri dan orang lain. Kemudian, pengajar melatihkan materi tersebut bersama pemelajar.

P: Halaman 4 itu ada Rini, teman-teman Rini. Saya membaca Mbak dan Mas mendengar, oke siap!

P: Nama saya Rini. Saya berasal dari Surabaya. Saya pemelajar di Universitas Negeri Malang. Saya belajar bahasa

Indonesia. Saya tinggal di rumah kos di jalan Surabaya, ya. Teman-teman Rini. Nama saya Asep. Saya berasal dari

Bandung. Saya belajar Biologi di Universitas Negeri Malang. Saya tinggal di Asrama Putra. Nama saya Ayu. Saya

berasal dari Malang. Saya belajar bahasa Inggris di UM. Saya sekarang tinggal di jalan Ambarawa. Saya Tari, saya

berasal dari Blitar. Saya belajar Ekonomi di UM. Saya tinggal di Asrama Putri. (a)

P: Ini Rini, nah! Kalau Mas Michael? (b)

M: Saya?

P: Nama lengkapnya siapa Mas? Nama lengkap Anda siapa? (c)

M: Anda? Nama lengkap?

P: Nama lengkap saya Risky Putri Ramadani $(d)$

M: Nama lengkap saya Michael Oman Raegan

P: Nama Panggilan Anda? Nama panggilan saya Risky (e)

M: Nama panggilan saya Mas Michael.

P: Mas Michael. Mas Michael ya. Mas berasal dari mana? ( $f$ )

M: saya berasal dari Oregon dan tinggal di New York

P: Mau bertanya? Mau bertanya? Silakan Mbak!

M: Eh. Eh. Anda Eh. Nama siapa siapa nama siapa nama panggilan Anda.

Materi pembelajaran pada dialog tersebut adalah informasi tentang identitas diri orang lain yang isinya berupa nama, asal, status, dan alamat. Sementara itu, ketika pengajar menambah informasi dengan bertanya nama lengkap (3c). Hal yang wajar jika pemelajar tidak mengetahui maksud pengajar karena pemelajar tidak tahu kosakata nama lengkap. Setelah pengajar memberikan contoh seperti pada tuturan (3d), pemelajar baru dapat memahami contoh tersebut.

Tujuan pengajar mengajukan pertanyaan adalah membantu pemelajar melihat hubungan-hubungan antara skemata yang dimiliki dengan informasi baru yang akan dipahami. Namun, hubungan-hubungan tersebut perlu dicermati dengan serius dengan cara yang tepat. Sesuai dengan indikator teknik pembangunan skemata bahwa ada informasi yang disajikan dalam hal ini sebuah bacaan yang dibacakan. Kemudian, pengajar membangun skemata dari informasi baru tersebut melalui skemata awal pemelajar dengan cara bertanya mengenai isi informasi baru yang disampaikan. Hal tersebut relevan dengan ciri-ciri bahasa pengajar adalah menginformasikan dan menjelaskan. teknik scaffolding tersebut berusaha memberikan informasi baru dan memahamkannya melalui penjelasan dan skemata yang sudah dimiliki pemelajar. Bahasa pengajar dikarakterisasi dengan banyaknya ujaran yang berbentuk menginformasikan, menjelaskan, mendefinisikan, menanyakan, membenarkan, memfokuskan, memeritah ataupun menyuruh (Ibrahim, 1993).

Pembangunan skemata berhubungan dengan fungsi memberikan informasi yang berupa contoh sebagai model atau informasi dalam bentuk teks tulis, audio visual, dan lain sebagainya. Pembelajaran scaffolding berperan penting khususnya dalam pembelajaran membaca. Pengajar berperan sebagai mediator dalam pembelajaran termasuk sebagai pemberi informasi bagi pemelajar. Zone Proximal Development (ZPD) merepresentasikan konsep penting dalam teori sosiokultural yang menjelaskan pentingnya peran pengajar sebagai mediator; ini merupakan inti dari pembelajaran scaffolding (Reza, Gh., \& Mahmood, 2012). Pengajar berperan menjadi mediator dalam memberikan informasi dan membantu pemelajar mencapai pemahaman sangat penting. 
Dengan demikian, teknik scaffoding pembangunan skemata yang muncul dalam pembeajaran BIPA di kelas pemula mendukung pendapat Walqui (2006). Namun, perlu dicermati berdasarkan data (3) terdapat bagian ketika pemelajar tidak memahami maksud ujaran pengajar dalam upaya melakukan scaffolding tersebut. Kemudian, pengajar berusaha memperhatikan isi materi yang disampaikan dan memberikan contoh ulang sehingga pemelajar dapat memahami maksud pengajar. Oleh sebab itu, pengajar harus lebih memberikan perhatian dan merencanakan pembelajaran lebih baik lagi sehingga tidak terjadi kesalahpahaman antara pemelajar dan pengajar.

\section{Pengembangan Metakognisi dan Fungsinya}

Metakognisi dimengerti sebagai kemampuan untuk memonitor salah satu tingkat dari pemahaman (Bransford, Broen, \& Cocking, 1999). Hal tersebut mengacu pada cara-cara yang digunakan pemelajar dalam mengatur pikiran mereka (Walqui, 2006). Metakognisi menengahi antara kognisi dan pemelajar (Holton \& Clarke, 2006). Berdasar pendapat tersebut, scaffolding dapat membantu pemelajar membuat hubungan antara kognisi dan proses berpikir mereka. Berdasar data yang ditemukan dalam interaksi pembelajaran BIPA di kelas pemula, setelah mendapatkan informasi, pemelajar diminta oleh pengajar untuk bertanya kepada teman sejawat mengenai materi yang dipelajari. Interaksi percakapan antar pemelajar tersebut dapat melatih kemampuan berkomunikasi dalam bahasa Indonesia dan melatihkan materi yang diajarkan. Data yang disajikan berikut merupakan bentuk pengembangan metakognisi karena sesuai dengan aspek-aspek dalam membangun metakognisi pemahaman pemelajar.

(4) Konteks: Pengajar meminta pemelajaruntuk bertanya kepada teman sejawat setelah mempelajari materi yang diajarkan P:(pengajar mencontohkan bagaimana membuat kalimat bahasa Indonesia yang baik dan benar)

P: Oh ya, Mbak Julia tanya Mbak Kathryn silakan! (a)

M: Mbak Kathryn siapa nama tutor Anda?

M: Eh, nama tutor saya Marintan, Mbak Marintan

M: em, berasal dari mana?

M: tutor saya berasal dari Malang.

Data (4a) tersebut menunjukkan, setelah mendapatkan informasi pemelajar diminta oleh pengajar untuk bertanya kepada teman sejawat mengenai materi yang dipelajari. Dalam percakapan tersebut, terjadi interaksi antar pemelajar yang dapat melatih kemampuan berkomunikasi dalam bahasa Indonesia dan melatihkan materi yang diajarkan. Pengajar mendorong pemelajar untuk memonitor proses belajar dan berpikirnya. Pengajar membimbing pemelajar dalam mengembangkan strategi-strategi belajar yang efektif dengan cara melibatkan mereka aktif dalam kegiatan pembelajaran. Pengajar membimbing pemelajar untuk mengembangkan kebiasaan bertanya sebagaimana terlihat dalam data-data tersebut.

Penelitian terdahulu mengenai scaffolding menunjukkan bahwa scaffolding membantu pemelajar meningkatkan metakognisinya, membuat materi lebih mudah dipahami (Holton \& Clarke, 2006). Strategi pembelajaran bahasa kedua salah satunya adalah strategi metakognitif. Metakognitif merupakan suatu istilah yang digunakan dalam teori pemrosesan informasi untuk menunjukkan fungsi "eksekutif", adalah strategi yang melibatkan perencanaan belajar, pemikiran tentang proses pembelajaran yang sedang berlangsung, pemantauan produksi dan pemahaman seseorang, dan evaluasi pembelajaran setelah sebuah aktivitas selesai (Brown, 2007). Bentuk scaffolding tersebut menunjukkan bahwa pengajar memberikan pemikiran tentang proses pembelajaran yang sedang berlangsung, pemantauan produksi, dan pemahaman seseorang dengan cara meminta pemelajar untuk bertanya kepada teman sejawat. Pemelajar akan merespons dan bertanya kepada teman sejawat sehingga akan terjadi produksi bahasa dalam interaksi. Jika terjadi interaksi, berarti pemelajar dianggap sudah memahami materi yang disampaikan pengajar.

Bentuk tersebut berhubungan dengan fungsi membimbing. Pengajar membimbing pemelajar untuk mengembangkan kebiasaan bertanya sebagaimana terlihat dalam data-data tersebut. Temuan itu mendukung pendapat bahwa scaffolding bukan sekadar sebuah bantuan semata kepada pemelajar, melainkan juga sebuah dukungan kepada pemelajar dalam rangka memperoleh pengetahuan baru yang lebih kompleks untuk dapat menyelesaikan tugas-tugas pada konteks yang baru (Hammond \& Gibbons, 2008). Hal tersebut mendukung pemelajar untuk mengetahui materi pembelajaran dengan baik.

Fungsi membimbing berhubungan juga dengan temuan Pea (2004) bahwa salah satu ciri scaffolding yang telah ditemukan adalah pemfokusan. Artinya, pengajar berusaha membimbing pemelajar untuk tetap fokus pada pencapaian tujuan pembelajaran. Kehadiran scaffolding pengembangan metakognisi dalam pembelajaran BIPA di kelas pemula mendukung pendapat Walqui (2006) bahwa pengajar membantu pemelajar mengelola pikiran mereka dengan menerapkan empat aspek berikut. (1) secara sadar penerapan strategi belajar dan terlibat dalam aktivitas pembelajaran, (2) pengetahuan dan kesadaran untuk memilih strategi belajar yang efektif, (3) mengamati, mengevaluasi, dan menyesuaikan pelaksanaan selama aktivitas berlangsung, serta (4) perencanaan untuk waktu kedepan berdasarkan evaluasi pelaksanaan yang lalu. Sebagaimana yang telah disebutkan dalam pembahasan ini, pengajar berusaha memonitor, membimbing, dan mengembangkan strategi belajar yang efektif dengan cara melibatkan pemelajar aktif dalam aktivitas pembelajaran. 


\section{Kontekstualisasi dan Fungsinya}

Penghadiran konteks melalui objek otentik dan sumber informasi lain seperti foto, penggalan film, dan objek otentik lainnya dapat membuat bahasa lebih mudah dipahami oleh pemelajar. Selain itu, pengajar mungkin dapat menggunakan kontekstualisasi verbal dengan menghadirkan analogi-analogi berdasarkan pengalaman pemelajar (Walqui, 2006). Bentuk kontekstualisasi diklasifikasikan menjadi dua (1) kontekstualiasi verbal, dan (2) kontekstualisasi non-verbal. Namun, dalam interaksi pembelajaran BIPA di kelas pemula ini menunjukkan bahwa kontekstualiasasi verbal dan non-verbal dalam konteks khusus saling melengkapi satu sama lain. Hal tersebut tampak situasi saat pengajar menjelaskan sebuah kata yang membutuhkan kehadiran kedua bentuk kontekstualisasi misalnya kata "bertemu" pada data berikut.

(5) Konteks: Pemelajar bertanya tentang arti kata bertemu. Kemudian, pengajar menjelaskan kosakata tersebut.

M: Bertemu apa?

P1: Bertemu, hai Mbak! (a)

P2: Hai Mas Basori. (b)

P1: Hai Mbak (c)

P2: Apa kabar? (d)

P1: Baik. Ini bertemu(e)

M: Apa greet?

P1: Greet, selamat pagi, selamat siang. Hmm, di Mall bertemu, nanti siang bertemu peer tutor $(f)$

M: Bertemu

P1: Ya bertemu.

Data (5a-5f) tersebut menunjukkan bahwa pengajar berusaha menjelaskan kata bertemu dengan menghadirkan sebuah konteks penggunaan kata bertemu dengan cara membangun situasi disertai sebuah peragaan. Namun, dalam data tersebut terlihat pemelajar belum dapat mengerti karena ada ungkapan hai. Pemelajar memahaminya sebagai ungkapan salam untuk menyapa seseorang. Pengajar berusaha menyajikan kembali informasi berdasarkan konteks yang lebih dekat dengan pemelajar dalam tuturan, misalnya aktivitas sehari-harinya nanti siang bertemu peer tutor. Setelah itu pemelajar dapat lebih memahami kata bertemu.

Dukungan kontekstual merupakan salah satu bentuk scaffolding yang digunakan dalam pembelajaran. Kontekstualisasi yang dilakukan pengajar memiliki fungsi menjelaskan karena pengajar memberikan sebuah peragaan untuk menjelaskan kosakata baru. Pengajar menjelaskan kosakata panas dan dingin dengan cara menghadirkan konteks kosakata tersebut. Pengajar bersikap seolah seperti orang yang sedang kepanasan yang mengibaskan kipas. Selanjutnya, ketika menjelaskan kata dingin pengajar bersikap sedang kedinginan dan mendekap tubuhnya sambil menggigil. Sementara itu, pengajar menjelaskan kosakata meletakkan dengan cara memperagakan secara langsung. Pengajar mengambil spidol dan meletakkannya di atas meja pengajar.

Fenomena seperti itu sering terjadi dalam pembelajaran BIPA. Pemelajar yang tidak mengerti kosakata baru akan bertanya kepada pengajar. Ada beberapa masalah dalam hal tersebut, (1) topik pembelajaran yang berkaitan erat dengan pemilihan kosakata baru, (2) pengajar tidak tahu bahasa pertama pemelajar, (3) belum tentu semua pemelajar BIPA mengerti bahasa Inggris, dan (4) latar belakang budaya yang berbeda. Dengan mempertimbangkan hal-hal tersebut, perlu ada fungsi penjelas supaya masalah kosakata baru yang dihadapi pemelajar teratasi. Pemelajar memerlukan contoh yang jelas dalam pembelajaran. Selain itu, dalam memberikan kosakata baru untuk pemelajar harus diperhatikan tingkat kemahiran pemelajar sesuai acuan pemeringkatan yang digunakan. Nisbet (2010) menawarkan petunjuk praktis untuk mengimplementasikan pengajaran kosakata menggunakan tiga tingkatan susunan kosakata: kata dasar yang banyak digunakan, kata yang frekuensi penggunaannya tinggi, dan kata yang frekuensi penggunaannya rendah.

Berkaitan dengan bahasa pengajar, pertama, penyesuaian formal terjadi pada semua tingkat (pemula, madya, dan lanjut), kedua, pada umumnya pengajar berusaha agar apa yang diucapkannya tidak bertentangan dengan penggunaan bahasa yang baik dan benar, dan ketiga, seperti bahasa Mama dan bahasa Rangsing, bahasa Cigu penuh dengan penyesuaian-penyesuaian interaksional (ulangan, jeda diperpanjang, suara diperkeras, dan sebagainya) (Baradja, 1990). Oleh karena itu, kontekstualisasi yang disajikan harus mempertimbangkan tingkat kemahiran pemelajar. Dalam pembelajaran kelas pemula, tentu terdapat banyak penyesuaian dan penyederhanaan yang dilakukan pengajar ketika mendemonstrasikan sebuah materi.

Scaffolding bukan sekadar sebuah bantuan semata kepada pemelajar, melainkan juga sebuah dukungan kepada pemelajar dalam rangka memperoleh pengetahuan baru yang lebih kompleks untuk dapat menyelesaikan tugas-tugas pada konteks yang baru (Hammond, J \& Gibbons, 2008). Pendapat tersebut selaras dengan hal yang terjadi dalam kasus penggalan transkrip di atas. Pemelajar BIPA yang belum mengetahui sebuah kosakata baru dibantu oleh pengajar dengan cara yang sesuai. Pengetahuan tentang kosakata yang sesuai dengan topik pembelajaran nantinya akan mendukung pemelajar untuk memahami materi pembelajaran yang lebih kompleks.

Scaffolding merupakan bantuan kebahasaan yang digunakan untuk membangun percakapan bersama antara penutur asli dan pemelajar bahasa asing dalam sebuah intraksi dengan cara menuntun dan membantu pemelajar untuk menyelesaikan wacana (Freeman \& Long, 1991). Scaffolding bukan sekadar sebuah bantuan semata kepada pemelajar, melainkan juga sebuah dukungan kepada pemelajar dalam rangka memperoleh pengetahuan baru yang lebih kompleks untuk dapat menyelesaikan tugas-tugas pada konteks yang baru (Hammond \& Gibbons, 2008). Selain itu, pengajar mendukung pemelajar untuk mengetahui bagaimana bukan sekadar apa. 
Pengertian yang diberikan Walqui (2006) bahwa penghadiran konteks melalui objek otentik dan sumber informasi lain seperti foto, penggalan film, dan objek otentik lainnya dapat membuat bahasa dipahami dengan mudah oleh pemelajar. Selain itu, pengajar mungkin dapat menggunakan kontekstualisasi verbal dengan menghadirkan analogi-analogi berdasarkan pengalaman pemelajar. Pendapat tersebut memang benar adanya, tetapi dalam kondisi tertentu upaya kontekstualiasasi tidak sebatas dua hal yang berbeda antara verbal non verbal karena kadang keduanya hadir dan saling melengkapi sebagaimana pada data (5a-f). Dengan demikian, teknik scaffolding kontekstualsasi yang tampak dalam pembelajaran di kelas pemula tersebut memberikan pengertian tambahan untuk pendapat tersebut.

\section{Ilustrasi dan Fungsinya}

Bahasa pengajar dikarakterisasi dengan banyaknya ujaran yang berbentuk menginformasikan, menjelaskan, mendefinisikan, menanyakan, membenarkan, memfokuskan, memerintah ataupun menyuruh (Ibrahim, 1993). Berdasar pendapat tersebut dapat ditambahkan bahwa ketika pengajar menjelaskan suatu informasi baru, memerlukan aspek lain yaitu pemberian ilustrasi dan juga pemberian contoh ketika mengajar di kelas. Oleh karena itu, informasi baru tidak cukup diinformasikan atau dijelaskan saja apalagi hanya didefinisikan. Pengajar juga perlu membuat ilustrasi dan memberikan contoh apalagi dalam pembelajaran BIPA yang pemelajarnya adalah orang asing yang memiliki bahasa dan budaya yang berbeda dengan Indonesia. Artinya, temuan ini menunjukkan bahwa pembelajaran BIPA memiliki ciri khas tersendiri dibandingkan dengan pembelajaran lain.

Bentuk scaffolding terdapat enam tipe yaitu pemodelan, kontekstualisasi, penyajian ulang teks, penghubung, pembangunan skemata, dan pengembangan metakognisi (Walqui, 2006). Namun, ada bentuk lain yang muncul dan dibutuhkan ketika mengajar pemelajar BIPA. Bentuk itu berhubungan dengan bentuk kontekstualisasi, yakni bentuk ilustrasi. Ketika menghadirkan sebuah situasi untuk memahamkan pemelajar tentu perlu adanya pemberian ilustrasi dan contoh. Walqui (2006) telah menjelaskan bahwa pemelajar membutuhkan contoh yang jelas untuk dapat ditiru. Pendapat Walqui tersebut diperuntukkan untuk bentuk pemodelan. Namun, selain pemodelan, ada hal lain yang membutuhkan contoh yang jelas. Sebagaimana pada data berikut.

(6) Konteks: PemelajarBIPA bertanya arti kosa kata baru yang tidak dimengerti kepada pengajar

P: Nah Bu Sri bekerja di mana?

M: tidak tahu (tertawa)

P: bertanya Mbak!

$\mathrm{M} 1:$ Bu Sri bekerja di mana?

M2: Toko

M1: Toko?

P: Tempat membeli $(a)$

M1: Oke

P: Membeli di toko Bu Sri?

M1: Tidak

Data (6a) menunjukkan pengajar juga menggunakan bentuk ilustrasi untuk menjelaskan kata toko. Artinya setelah aktivitas pemodelan pengajar akan menerima pertanyaan dari pemelajar. Dalam pembelajaran BIPA tentu akan muncul pertanyaan tentang kosakata baru yang belum dimengerti pemelajar sebagaimana dicontohkan pada data tersebut. Kosakata adalah hal penting dalam pembelajaran bahasa dan komponen esensial dalam menambah kelancaran pemerolehan bahasa kedua. Kosakata adalah bagian terbesar dalam arti bahasa apapun dan kosakata adalah masalah tervesar bagi sebagian besar pemelajar (Safian, H.N, Malakar.S, \& Kalajahi, 2014). Bentuk ini berhubungan dengan fungsi menjelaskan. Sebagaimana sudah dijelaskan di bagian bentuk kontekstualisasi. Kehadiran scaffolding ilustrasi dalam pembelajaran BIPA di kelas pemula ini memberikan tambahan untuk teori yang sudah dikemukakan oleh Walqui (2006) bahwa bentuk scaffolding terdapat enam tipe yaitu pemodelan, kontekstualisasi, penyajian ulang teks, penghubung, pembangunan skemata, dan pengembangan metakognisi.

\section{Peragaan dan Fungsinya}

Bentuk peragaan muncul berdasar kasus serupa dengan bentuk ilustrasi, yaitu ketika pemelajar bertanya mengenai kosakata sulit. Bentuk itu berhubungan dengan bentuk kontekstualisasi. Selain kontekstualisasi dan ilustrasi pengajar BIPA juga melakukan bentuk peragaan ketika membantu pemelajar untuk memahami informasi baru. Bahasa pengajar dikarakterisasi dengan banyaknya ujaran yang berbentuk menginformasikan, menjelaskan, mendefinisikan, menanyakan, membenarkan, memfokuskan, memeritah ataupun menyuruh (Ibrahim, 1993). Sebagaimana pembahasan sebelumnya mengenai ilustrasi, karakteristik bahasa pengajar tidak cukup menginformasikan, menjelaskan, bahkan mendefinisikan saja. Dalam pembelajaran BIPA, ketiga karakteristik tersebut dinilai belum cukup karena pengajar masih memerlukan tindakan lain. Pengajar BIPA masih memerlukan tindakan berupa memberikan ilustrasi, memberikan contoh, bahkan memberikan peragaan. Pengajar BIPA melibatkan seluruh anggota tubuh untuk membantu pemelajar memahami sebuah informasi baru. Temuan ini sekali lagi membuktikan bahwa pembelajaran BIPA memiliki ciri khas tersendiri dalam bidang pembelajaran khususnya bahasa Indonesia. Sebagaimana pada data berikut. 
(7) Konteks: Pengajar menjelaskan kosa kata yang tidak dimengerti oleh pemelajar M: Apa panas dan dingin?

P: Panas (melakukan gerakan kipas-kipas ketika orang kepanasan), dingin (melakukan gerakan mendekap tubuh ketika orang kedinginan).

M: Oh, terima kasih.

Pengajar menjelaskan kosakata baru yang ditanyakan pemelajar dengan teknik scaffolding berupa bentuk kontekstuasliasi, ilustrasi, dan peragaan. Kemunculan bentu-bentuk tersebut dipengaruhi kosakata yang dipertanyakan pemelajar. Hal ini membuktikan bahwa akan muncul bentuk scaffolding lain sesuai kondisi yang melatar belakanginya, baik jenis kata, topik materi, maupun cara penjelasan pengajar. Kajian mengenai kosakata sangat menarik dan perlu dikaji lebih lanjut, karena pemerolehan makna kosakata yang sulit akan berkelanjutan. Selain itu, eksplorasi metode penjelasan kosakata baru yang efektif menjadi sebuah tantangan dan proses yang berkelanjutan (Wangru, 2016).

Bentuk itu berbeda dengan pemodelan. Pemodelan dihadirkan untuk memberikan sebuah contoh ideal yang dapat ditiru pemelajar, sedangkan bentuk peragaan ini hadir hanya untuk menjelaskan pertanyaan yang diajukan pemelajar atau di saat pemelajar mengalami kesulitan dalam memahami materi. Oleh karena itu, bentuk peragaan berhubungan dengan fungsi menjelaskan sebagaimana dijelaskan dalam bagian bentuk kontekstualisasi.

\section{Koreksi dan Fungsinya}

Bentuk koreksi dilakukan oleh pengajar untuk menjaga pemelajar melaksanakan tugas dengan benar dan tetap fokus dan termotivasi sehingga dapat mencapai tujuan pembelajaran. Pengajar yang baik juga mempertahankan arahannya yang berharga bagi pemelajar untuk melangkah ke tahap berikutnya (Hall, 2001) Pengajar berusaha mengoreksi pemahaman pemelajar yang salah tentang kosakata yang telah ia peroleh.

(8) Konteks: Pemelajar mempertanyakan kata mengajar dan belajar. Pengajar berusaha memberikan penjelasan untuk meluruskan pemahaman pemelajar.

M: Kenapa tidak sama? Why saya belajar Anda mengajar?

P: Saya mengajar dan Anda belajar, iya struktur sama, tapi kata berbeda. Oke pengajar mengajar bahasa Indonesia, pemelajar belajar bahasa Indonesia (menulis di papan tulis)

Fungsi itu hadir dalam bentuk koreksi yang diberikan pengajar ketika pemelajar melakukan kesalahan. Fungsi untuk menjaga pemelajar melaksanakan tugas dengan benar dan menjaga tetap fokus dan termotivasi sehingga dapat mencapai tujuan pembelajaran. Pengajar yang baik juga mempertahankan arahannya yang berharga bagi pemelajar untuk melangkah ke tahap berikutnya.

Bahasa pengajar dikarakterisasi dengan banyaknya ujaran yang berbentuk menginformasikan, menjelaskan, mendefinisikan, menanyakan, membenarkan, memfokuskan, memeritah ataupun menyuruh (Ibrahim, 1993). Fungsi mengarahkan ini berbentuk tindakan koreksi yang diberikan oleh pengajar ketika pemelajar melakukan kesalahan. Hal tersebut memang sesuai dengan karakter bahasa pengajar, yaitu ciri membenarkan sebagaimana dalam pendapat tersebut.

Bentuk koreksi berhubungan dengan fungsi mengarahkan. Fungsi untuk mengarahkan pemelajar melaksanakan tugas dengan benar serta menjaga tetap fokus dan termotivasi dilakukan agar mencapai tujuan pembelajaran. Pengajar yang baik juga mempertahankan arahannya yang berharga bagi pemelajar untuk melangkah ke tahap berikutnya (Wood, Bruner, \& Ross, 1976). Teori tersebut dipahami sebagai saran bagi pengajar, pengajar yang baik selalu berusaha menjaga dan mengarahkan pemelajar ketika pemelajar melakukan kesalahan. Upaya tersebut berharga bagi pemelajar karena dapat membantu pemelajar untuk belajar dengan baik.

Dengan demikian, kehadiran teknik scaffolding ilustrasi, peragaan, dan koreksi dalam pembelajaran BIPA di kelas pemula ini memberikan tambahan untuk teori yang sudah dikemukakan oleh Walqui (2006) bahwa bentuk scaffolding terdapat enam tipe, yaitu pemodelan, kontekstualisasi, penyajian ulang teks, penghubung, pembangunan skemata, dan pengembangan metakognisi. Dalam kondisi tertentu khususnya pembelajaran BIPA, ternyata menghadirkan bentuk dan fungsi scaffolding lain. Di kelas pemula teknik penyajian ulang teks tidak muncul karena faktor kondisi kemampuan pemelajar yang masih dalam tahap awal belajar bahasa. Artinya, penggunaan teknik scaffolding juga dipengaruhi oleh jenis pembelajaran yang dilaksanakan. Pembelajaran bahasa Inggris, pembelajaran bahasa Indonesia bagi orang Indonesia, pembelajaran bahasa lain, dan khususnya pembelajaran BIPA memberikan nuansa berbeda dan ciri khas dari pembelajaran masing-masing.

\section{SIMPULAN}

Bentuk scaffolding yang terekam dalam pembelajaran BIPA di kelas pemula, meliputi (1) pemodelan, (2) penghubung (3) pembangunan skemata, (4) pengembangan metakognisi, (5) kontekstualisasi, (6) ilustrasi, (7) peragaan, dan (8) koreksi. Pemodelan merupakan salah satu bentuk scaffolding yang sering digunakan dalam pembelajaran. Pemodelan memiliki peran penting dalam penyampaian materi baru. Jenis pemodelan yang muncul dipengaruhi oleh jenis topik atau materi yang diajarkan. Selanjutnya, bentuk penghubung digunakan untuk menghubungkan informasi yang pernah dialami pemelajar sebagai jembatan untuk mempermudah pemelajar dalam memahami materi yang akan dipelajari. 
Bentuk pembangunan skemata dipengaruhi kemampuan pemelajar dalam memahami materi dan skemata yang telah dimiliki untuk meningkatkan pengetahuan pemelajar melalui informasi tentang materi yang dipelajari. Di sisi lain, pengembangan metakognisi dilakukan pengajar untuk membantu pemelajar meningkatkan metakognisinya sehingga pemelajar lebih mudah memahami materi yang dipelajari.

Bentuk kontekstualisasi dapat berupa kontekstualiasasi verbal dan non-verbal. Dalam pembelajaran BIPA di kelas pemula ini kontekstualisasi muncul dan saling melengkapi satu sama lain. Bentuk kontekstualisasi yang muncul sesuai dengan kosakata baru yang dipertanyakan dan dijelaskan dengan cara menghadirkan konteks yang sesuai. Begitu pula pada bentuk peragaan dan ilustrasi. Oleh karena itu, kemungkinan munculnya kontekstualisasi, peragaan, dan ilustrasi dengan cara lain sangat memungkinkan.

Fenomena tersebut sering terjadi dalam pembelajaran BIPA. Pemelajar yang tidak mengerti kosakata baru akan bertanya kepada pengajar. Ada beberapa hal mendasar yang memengaruhi hal tersebut, yaitu (1) topik pembelajaran yang berkaitan erat dengan pemilihan kosakata baru, (2) pengajar tidak tahu bahasa pertama pemelajar, (3) belum tentu semua pemelajar BIPA mengerti bahasa asing lain, dan (4) latar belakang budaya yang berbeda. Selain itu, dalam memberikan kosakata baru untuk pemelajar, pengajar harus memperhatikan tingkat kemahiran pemelajar sesuai acuan pemeringkatan yang digunakan. Sementara itu, koreksi dilakukan oleh pengajar untuk menjaga pemelajar melaksanakan tugas dengan benar dan menjaga mereka tetap fokus dan termotivasi sehingga dapat mencapai tujuan pembelajaran.

Fungsi scaffolding ditemukan dalam interaksi pembelajaran BIPA di kelas pemula, meliputi (1) mendemonstrasikan, (2) memfokuskan, (3) memberikan informasi, (4) membimbing, (5) menjelaskan, dan (6) mengarahkan. Fungsi-fungsi tersebut berhubungan dengan bentuk-bentuk scaffolding yang tampak dalam pembelajaran BIPA. (a) fungsi mendemonstrasikan berhubungan dengan bentuk pemodelan (b) fungsi memfokuskan berhubungan dengan bentuk penghubung, (c) fungsi memberikan informasi berhubungan dengan bentuk pembangunan skemata, (d) fungsi membimbing berhubungan dengan bentuk pengembangan metakognisi, (e) fungsi menjelaskan berhubungan dengan bentuk kontekstualisasi, ilustrasi, dan peragaan, dan (f) fungsi mengarahkan berhubungan dengan bentuk koreksi.

Kemunculan berbagai bentuk dan fungsi scaffolding dalam pembelajaran BIPA di kelas pemula memberikan pengertian bahwa pengajar BIPA memiliki ciri khusus. Variasi kemunculan bentuk dan fungsi scaffolding tersebut dipengaruhi beberapa faktor di antaranya, (1) jenis pembelajaran, (2) topik atau materi yang diajarkan, (3) kemampuan pemelajar dan pengajar, (4) tingkat kemahiran pemelajar, dan (5) latar belakang budaya pemelajar. Berdasarkan faktor-faktor tersebut pengajar BIPA memerlukan teknik pembelajaran khusus untuk membantu pemelajar memahami bahasa Indonesia yang berbeda dengan bahasa asli mereka. Oleh karena itu, scaffolding sebagai teknik yang digunakan untuk menjembatani pemelajar dalam memahami bahasa Indonesia sangat diperlukan.

Berdasarkan hasil penelitian, dijelaskan pula saran yang berhubungan dengan pengembangan ilmu secara teoretis serta penerapan ilmu secara praktis. Secara teoretis, temuan penelitian yang berupa bentuk dan fungsi scaffolding dalam pembelajaran BIPA ini dapat menjadi referensi keilmuan, khususnya bidang BIPA. Adapun saran tersebut dijelaskan sebagai berikut.

Pertama, bagi pengajar BIPA disarankan untuk menyadari peranan scaffolding dalam pembelajaran. Pembelajaran bahasa Indonesia sebagai bahasa asing membawa ciri khusus. Pengajar diharapkan mampu menyampaikan konsep bahasa Indonesia, struktur kalimat bahasa Indonesia, kelogisan dalam berbahasa Indonesia, dan keberterimaan dalam berbahasa Indonesia kepada pemelajar BIPA. Artinya, pengajar mengemban tugas membuat pemelajar BIPA mampu berbahasa Indonesia dengan baik. Ada aspek khusus yang menjadi salah satu masalah ketika mengajarkan bahasa Indonesia yakni menjelaskan kosaskata baru kepada pemelajar BIPA. Pengajar BIPA harus mengontrol kosakata yang diajarkan. Pengajar juga mempersiapkan sebuah materi ajar BIPA perlu mempertimbangkan penggunaan kosakatanya. Setiap tingkat kemahiran memiliki batasan topik sehingga pengajar BIPA harus menentukan kosakata yang sesuai dengan tingkat kemahiran pemelajar.

Kedua, bagi peneliti selanjutnya, dapat mengembangkan lebih lanjut ruang lingkup sasaran penelitian terhadap kajian pembelajaran BIPA. Masih banyak fitur-fitur scaffolding yang dapat diteliti. Perlu diketahui bahwa variasi kemunculan bentuk scaffolding yang tampak dalam pembelajaran BIPA juga dipengaruhi beberapa faktor, di antaranya (1) jenis pembelajaran, (2) topik atau materi yang diajarkan, (3) kemampuan pemelajar dan pengajar, (4) tingkat kemahiran pemelajar, serta (5) latar belakang budaya pemelajar. Artinya, ada kemungkinan muncul bentuk dan fungsi lain dalam latar pembelajaran BIPA. Selain itu, temuan penelitian ini diharapkan dapat dijadikan alternatif pengembangan pembelajaran BIPA.

\section{DAFTAR RUJUKAN}

Abdullah, S. (2015). Ego is a Hurdle in Second Language Learning: A Contrastive Study between Adults and Children. Advances in Language and Literary Studies, 6(6), 173. https://doi.org/10.7575/aiac.alls.v.6n.6 hlm.170

Akhter, J., Amin, M., Saeed, F., Muhammad, K., \& Abdullah, S. (2016). Comparison and Contrast between First and Second Language Learning. Advances in Language and Literary Studies Australian International Academic Centre, 6(1), 133.

Azabdaftari, B. (2013). On The Implication of Vygotskian Concepts for Second Language Teaching. Iranian Journal of Language Teaching Research, 1(2), 99-114.

Baradja, M. (1990). Kapita Selekta Pengajaran Bahasa. Malang: IKIP Malang.

Bransford, J., Broen, A., \& Cocking, R. (1999). How People Learn. Brain, Mind, Experience, and School. Washington DC: National Academy Press. 
Brown, D. H. (2007). Prinsip Pembelajaran dan Pengajaran Bahasa, Edisi Kelima (5th ed.; N. C. and Avianto \& Yusi, eds.). Jakarta: Kedutaan Besar Amerika Serikat.

Freeman, D. L., \& Long, M. H. (1991). An Introduction to Second Language Acquisition Research. London: Longman.

Hall, J. K. (2001). Methods for Teaching Foreign Languages. New Jersey: Merrill Prentice-Hall.

Hammond, J dan Gibbons, P. (2008). Teacher's Voices 8 Esplicitly Supporting Reading and Writing in The Classroom. Australia: Maquarie University.

Holton, D., \& Clarke, D. (2006). Scaffolding and Metacognition. International Journal of Mathematical Education in Science and Technology, 2(37).

Ibrahim, S. (1993). Kajian Tindak Tutur. Surabaya: Usaha Nasional.

Pea, R. D. (2004). The Social and Technological Dimensions of Scaffolding and Related Theoretical concepts for Learning, Education, and Human Activity. The Journal of the Learning Sciences, 13(3), 423.

Reza, Gh., \& Mahmood, D. (2012). Sociocultural Theory and Reading Comprehension: The Scaffolding of Readers in An EFL Context. International Journal of Research Studies in Language Learning, 2(3).

Safian, H. N., Malakar, S., \& Kalajahi, R. (2014). Exploring Vocabulary Learning Strategies Used by UPM TESL Undergraduates. Advanced in Language and Literacy Studies, 5(5), 2.

Tharp, R. G., \& Gallimore, R. (1990). Teaching Mind in Society: Teaching, Schooling, and Literate Discourse. In L. C. Moll (Ed.), Vygotsky and Education: Instructional Implications And Applications Of Sociohistorical Psychology. Cambridge: Cambridge University Press.

Walqui, A. (2006). Scaffolding Instruction for English Language Learners: A Conceptual Framework. The Internasional Journal of Bilingual Education and Bilingualism, 9(2).

Wangru, C. (2016). Vocabulary Teaching Based on Semantic-Field. .. Journal of Education and Learning, 3(5).

Wood, D., Bruner, J. S., \& Ross, G. (1976). The Role of Tutoring in Problem Solving. Journal of Child Psycology and Psychiatry, 17(18).

Zhao, R., \& Chen, J. L. (2014). Scaffolding, perceived usefulness, satisfaction and continuance intention toward online foreign language learning. In F. Li (Ed.), Language, Medias and Culture III; International Proceedings of Economi s Development and Research. Singapore: IACSIT Press. 